\title{
WYBORY PARLAMENTARNE W CZASIE PANDEMII COVID-19. PRZYKŁAD WYBORÓW LITEWSKICH W 2020 R.
}

\author{
PARLIAMENTARY ELECTIONS DURING THE COVID-19 \\ PANDEMIC: AN EXAMPLE OF THE LITHUANIAN ELECTIONS \\ IN 2020
}

Martinas Malużinas*

\begin{abstract}
- ABSTRAKT
Przedmiotem niniejszego artykułu są wybory parlamentarne w Republice Litewskiej. Podjęto się analizy przebiegu i uwarunkowań instytucjonalnych wyborów, które odbyły się na Litwie w październiku 2020 roku w czasie trwającej pandemii Covid-19. W artykule przeanalizowano takie elementy, jak: wyniki wyborów na Litwie w 2020 r., nowe regulacje wyborcze, a także zaimplementowane nowe techniki głosowania w czasie pandemii. Oprócz tego poruszono także zagadnienia przebiegu kampanii wyborczej, która prowadzona była $\mathrm{w}$ warunkach obostrzeń i ograniczeń, które miały zwiększyć bezpieczeństwo wyborców oraz zmniejszyć transmisję koronawirusa SARS-CoV-2.
\end{abstract}

Słowa kluczowe: Litwa; wybory parlamentarne; kampania wyborcza; pandemia Covid-19
The subject of this article are the parliamentary elections in the Republic of Lithuania. An analysis of the course and institutional conditions of the elections that took place in Lithuania in October 2020 during the ongoing Covid-19 pandemic was undertaken. The article analyzes such elements as: the results of the elections in Lithuania in 2020, new electoral regulations, as well as the implementation of new voting methods during the pandemic. In addition, the issues of the course of the election campaign were also raised, which was conducted in the conditions of restrictions that were made to increase the safety of voters and reduce the transmission of the SARS-CoV-2 coronavirus.

Keywords: Lithuania; parliamentary elections; election campaign; Covid-19 pandemic

\footnotetext{
* Uniwersytet Łódzki, Wydział Studiów Międzynarodowych i Politologicznych.
} 


\section{WPROWADZENIE}

Wybory powszechne w okresie pandemii COVID-19 stanowią wyjątkową sytuację, z którą nigdy wcześniej państwa nie miały do czynienia $\mathrm{w}$ tak dużej skali. To również duże wyzwanie z perspektywy organizacji bezpiecznych i demokratycznych wyborów w sytuacji nadzwyczajnej. $Z$ uwagi na fakt, iż koronowirus w szybkim tempie opanował cały świat, także większość państw europejskich zdecydowała się na wdrożenie twardego lockdown'u. Szybka transmisja koronawirusa i wprowadzone od wiosny 2020 r. restrykcje - m.in. ograniczenia w kontaktach społecznych, zakaz zgromadzeń publicznych i in. - wpłynęły na przełożenie wyborów parlamentarnych, prezydenckich, lokalnych i referendów zaplanowanych w wielu państwach na lata 2020-2021. Mimo istniejącego zagrożenia bezpieczeństwa zdrowotnego w niektórych państwach postanowiono zorganizować wybory, wprowadzając jednak szczególne środki sanitarne, dystans społeczny i inne rozwiązania mające zwiększyć bezpieczeństwo wyborców. Litwa należy właśnie do tych państw, gdzie zdecydowano się zorganizować elekcje w czasie pandemii.

Pandemia COVID-19 ujawniła, że zorganizowanie wyborów powszechnych w sytuacjach nadzwyczajnych jest wielkim wyzwaniem dla państw, które chcą je przeprowadzić w sposób bezpieczny i demokratyczny. W związku z tym wiele państw wprowadziło alternatywne metody głosowania, aby przy zachowaniu zasad bezpieczeństwa zagwarantować jak największej liczbie uprawnionych udział w wyborach i zapewnienie możliwie wysokiej frekwencji. Takie działania pokrywają się z wizją szkoły partycypacjonistów, dla których istotą demokracji jest uczestnictwo obywateli i włączanie ich w podejmowaniu decyzji politycznych m.in. w drodze wyborów i referendów (Gutman, 1998; Musiał-Karg \& Kapsa, 2020). Zwiększanie możliwości zaangażowania wyborczego obywateli odgrywa ważną rolę w realizacji zasady powszechności wyborów.

W pracach wielu badaczy podejmowana jest tematyka organizacji wyborów w sytuacji zagrożenia bezpieczeństwa zdrowotnego. Warto zwrócić uwagę na publikacje: Roberta Krimmera, Davida Dueñas-Cid, Julii Krivonosovej, a także Magdaleny Musiał-Karg i Izabeli Kapsy oraz innych autorów, którzy omawiają przebieg, kontekst i uwarunkowania instytucjonalnie wyborów organizowanych w czasie pandemii COVID-19 (Krimer, Dueñas-Cid, Krivonosova, 2021; Martin-Rozumilowicz, 2020; Musiał-Karg, 2016; Spinelli, 2020; Wagner, 2020; ). W szerszym kontekście problemy wyborów w sytuacjach nadzwyczajnych (katastrofy naturalne, takie jak: huragany, tornado, powodzie, trzęsienie ziemi 
i inne) omawiane są w tekstach: Sarah Birch, Fernanda Burila, Nica Cheesemana, Alistaira Clarka, Staffana Darnolfa, Susany Dodsworth, Larry Garber, Roxany Gutiérrez-Romero, Tanja Hollstein, Toby’ego S. Jamesa, Vasu Mohana, Koffi'ego Sawyera, Liny Eriksson i innych autorów (Birch, Buril, Cheeseman, Clark, Darnolf, Dodsworth, Garber, Gutiérrez-Romero, Hollstein, James, Vasu Mohan, Sawyer, 2020; Eriksson, 2016 i 2016; James, Alihodzic, 2020; James, Clarc, 2021; Repucci, Slipowitz, 2020; Seitz, Davis, 1984). Autorzy powyższych badań wskazują, że jeżeli zostanie podjęta decyzja przeprowadzenia wyborów w sytuacji nadzwyczajnej, to elity polityczne muszą wziąć pod uwagę trzy scenariusze: 1) przeprowadzenie wyborów w reżimie sanitarnym, 2) zorganizowanie wyborów korespondencyjnych oraz 3) przeprowadzenie wyborów internetowych. Warto odnotować, że w Polsce w wyborach prezydenckich latem 2020 r. zdecydowano się na połączenie wariantów pierwszego i drugiego (mimo początkowych planów wyborów w wersji all-postal voting) (Musiał-Karg, Kapsa, 2021).

Perspektywa badawcza w pracach wymienionych powyżej autorów pozwala odnieść się do przypadku wyborów na Litwie. Rząd litewski, decydując przeprowadzić wybory w warunkach pandemii, zmuszony był zastanowić się, w jaki sposób zorganizować głosowanie, by było ono bezpiecznie dla wyborców, jak również dla członków komisji wyborczych. W tym przypadku, biorąc pod uwagę trzy wymienione powyżej scenariusze, Litwa zdecydowała się realizować wariant pierwszy, wdrażając procedury bezpieczeństwa sanitarnego: zapewnienie dystansu społecznego, poszerzenie kręgu wyborców upoważnionych do głosowania w domu o dodatkowe grupy wyborców, wydłużenie czasu otwarcia lokali wyborczych, otwarcie mobilnych punktów wyborczych itp.

Celem niniejszego artykułu jest analiza wpływu pandemii COVID-19 na wybory parlamentarne w 2020 r., uwzględniając zarówno regulacje prawne przyjęte na potrzeby elekcji, jak i konsekwencje tych regulacji i szerszy kontekst pandemii dla przebiegu głosowania i poprzedzającej je kampanii wyborczej. Zamierzeniem autora jest analiza dość skromnych doświadczeń Litwy w przeprowadzeniu wyborów $\mathrm{w}$ reżimie sanitarnym, biorąc pod uwagę organizację wyborów w okresie pandemii COVID-19.

Zorganizowane w październiku 2020 r. wybory parlamentarne w Republice Litewskiej były najgorętszym i najczęściej komentowanym tematem w kraju. Stan zagrożenia epidemiologicznego wywołanego pandemią COVID-19 kategorycznie zmienił funkcjonowanie wielu instytucji publicznych. Eksperci, dziennikarze i politycy dyskutowali nad najbardziej skutecznymi sposobami przeprowadzenia wyborów w sposób bezpieczny i demokratyczny. Wskutek 
zaistniałej sytuacji niejednokrotnie rozważano ich przełożenie, jednakże wybory zostały przeprowadzone w zaplanowanym terminie. Niniejszy tekst stanowi próbę analizy przebiegu wyborów w sytuacji wystąpienia okoliczności nadzwyczajnych oraz odpowiedzi na pytanie dotyczące ewentualnego, niekorzystnego wpływu pandemii (tzn. drugiej fali pandemii koronowirusa) na przeprowadzenie bezpiecznych i demokratycznych wyborów w sposób prawidłowy w sytuacji m.in. ograniczonych możliwości prowadzenia kampanii wyborczej. Aby zrealizować cel badawczy, analizę oparto na case study, co pozwoliło przyjrzeć się szczegółowo konkretnemu przypadkowi i wyciągnąć wnioski co do przyczyn, przebiegu i wyników wyborów parlamentarnych na Litwie. Dzięki temu też możliwe było ukazanie, w jaki sposób sytuacja pandemiczna wypłynęła na proces wyborczy, organizację i przeprowadzenie elekcji. Uzasadnieniem wyboru analizowanego przypadku elekcji na Litwie jesienią 2020 r. są nadzwyczajne okoliczności, w jakich odbyły się wybory. W epicentrum pandemii i przy rosnącej z dnia na dzień liczbie ofiar i zakażonych politycy litewscy postanowili przeprowadzić wybory parlamentarne w zaplanowanym pierwotnie terminie, co przełożyło się na sam proces wyborczy, przebieg kampanii wyborczej oraz na wyniki wyborów. Uzupełnieniem metody case study będzie metoda instytucjonalno-prawna.

Punktem wyjścia prowadzonych rozważań, jest hipoteza zakładająca, iż pandemia COVID-19 miała wpływ na proces organizacji oraz przebieg wyborów na Litwie. W związku ze stanem zagrożenia zdrowia publicznego rządy państwowe zmuszone były do dostosowania rozwiązań wyborczych do zaistniałej sytuacji. Kolejna hipoteza badawcza zakłada, że pandemia miała wpływ na różne aspekty wyborów parlamentarnych w 2020 r., m.in. realizację zasady równości rywalizujących podmiotów, regulacje formalne, dotyczące techniki głosowania w warunkach reżimu sanitarnego oraz na tematy podnoszone przez partie polityczne w kampanii wyborczej.

Struktura artykułu została pomyślana tak, by zaprezentować zasady prawa wyborczego w wyborach do Sejmu oraz system wyborczy Litwy, wyniki wyborów i frekwencję, nowe regulacje prawne związane z głosowaniem, zaimplementowane nowe techniki głosowania w okresie pandemii, a także przebieg kampanii wyborczej.

Artykuł może przyczynić do rozwoju badań nad wyborami (nad procesem organizacji i przeprowadzenia wyborów w sytuacjach nadzwyczajnych) i może wykraczać poza case Litwy - będzie stanowić ważną wskazówkę dla innych państw w procesie organizowania bezpiecznych i demokratycznych wyborów. 


\section{ZASADY WYBORÓW I LITEWSKI SYSTEM WYBORCZY}

Zasady prawa wyborczego Litwy wyznacza Konstytucja Republiki Litewskiej z 1992 r. Są to klasyczne zasady charakterystyczne dla państw o ustroju demokratycznym. Zgodnie z art. 55 Konstytucji Seimas jest wybierany w pięcioprzymiotnikowych wyborach. Reprezentuje on wolę suwerena. Charakterystyczne, że cykliczność wyborów jest uznawana także za samodzielną zasadę wyborczą. Cel niniejszego artykułu nie zakłada zaprezentowania ogólnie uznawanych zasad wyborczych, lecz warto podkreślić, iż ustawodawca poświęcił sporo uwagi temu, by wybory na Litwie były demokratyczne: równe, tajne, powszechne, wolne i uczciwe (Vaigauskas, 2013). Niezwykle istotną zasadą litewskich wyborów jest zasada gwarancji, że wybory będą odbywały się w sposób transparentny. Temu zagadnieniu Konstytucja w szczególności poświęca wiele uwagi, dokonując sformułowania zasad prawa wyborczego i jej standardów.

Analizując z kolei system wyborczy Republiki Litewskiej, uznać go można za odmianę mieszanego systemu wyborczego charakterystycznego dla modelu segmentowego stosowanego na Ukrainie czy dawniej w Rosji (Szcześciło, 2016). Właściwym dla tego modelu jest to, iż występują w nim dwa pokrywające się szczeble okręgów wyborczych. Ponadto podział mandatów na obu szczeblach odbywa się niezależnie (Massicotte, Blais, 1999). Na pierwszym szczeblu wybieranych jest 71 deputowanych w 71 okręgach jednomandatowych ${ }^{1}$ utworzonych na podstawie liczby wyborców w nich mieszkających. Wybory odbywają się według ordynacji mieszanej. Na drugim szczeblu - 70 deputowanych wybieranych na jednym ogólnolitewskim okręgu wyborczym, a wybory odbywają się według ordynacji proporcjonalnej². Należy zauważyć, iż w jednym okręgu wielomandatowym, obejmującym całe terytorium Litwy, głosują wszyscy obywateli Litwy posiadający prawa wyborcze. Z tych względów litewski system wyborczy należy określić mianem mieszanego systemu wyborczego, stanowiącego najmłodszą grupę systemów wyborczych w teorii i praktyce demokracji3 ${ }^{3}$.

\footnotetext{
${ }^{1} \mathrm{~W}$ okręgach jednomandatowych obowiązuje zasada większości bezwzględnej.

2 Co istotne, obywatel litewski na każdym szczeblu ma po jednym głosie i może te głosy oddać na różne ugrupowania polityczne. Cechą charakterystyczną - z punktu widzenia polskich regulacji wyborczych - jest to, że granice okręgów wyborczych ustala Centralna Komisja Wyborcza Republiki Litewskiej. W Rzeczypospolitej o podziale na okręgi w wyborach sejmowych rozstrzyga ustawodawca.

3 Należy zaznaczyć, iż zgodnie z charakterystyką litewskiego systemu wyborczego do Seimasu z list partyjnych trafiają partie polityczne, które w części proporcjonalnej uzyskają powyżej 5\% głosów
} 
W praktyce wyborca otrzymuje dwie karty do głosowania. W karcie wyborczej przeznaczonej dla okręgu jednomandatowego umieszczony jest alfabetyczny spis kandydatów. Wyborca ma możliwość oddania jednego głosu. Z kolei na karcie wyborczej dla okręgu wielomandatowego umieszczona jest partyjna lista kandydatów. Kolejność nazwisk kandydatów jest dowolna i ustalana przez daną partię. Zgodnie $\mathrm{z}$ art. 66 Konstytucji głosowanie odbywa się w lokalu obwodowej komisji wyborczej ds. przeprowadzenia głosowania w obwodzie, gdzie wyborca głosuje poprzez zaznaczenie listy. W następnej kolejności wyborca może wybrać pięciu kandydatów $\mathrm{z}$ listy oraz każdemu $\mathrm{z}$ nich udzielić jednego głosu preferencyjnego (Zieliński, 2003).

Zgodnie z ordynacją wyborczą czynne prawo wyborcze przysługuje wszystkim obywatelom, którzy ukończyli co najmniej 18. rok życia. Bierne prawo wyborcze do Sejmu Republiki Litewskiej ma również każdy obywatel, który ukończył 25 lat.

\section{WYBORY W CZASIE PANDEMII}

\section{Regulacje prawne związane z głosowaniem}

Analizując regulacje prawne związane z głosowaniem w czasie pandemii, należy stwierdzić, że jeszcze po 2016 r. podczas wyborów do Seimasu zmieniono kilka ustaw związanych $\mathrm{z}$ wyborami ${ }^{4}$. Zgodnie ze zmianami legislacyjnymi przyjętymi w tym czasie utworzono specjalny okręg wyborczy dla obywateli stale mieszkających lub tymczasowo przybywających za granicą Republiki Litewskiej. Utworzono rezerwę członków komisji wyborczych oraz stworzono warunki do składania wstępnych sprawozdań z finansowania kampanii politycznych. Skonstruowano dodatkowe środki gwarantujące prawo głosu dla wyborców niepełnosprawnych oraz przepisy dotyczące rejestracji kandydatów, alternatywnych sposobów głosowania i głosowanie za granicą. Zgodnie z nowelizacją Ustawy

- klauzula zaporowa. W okręgach jednomandatowych obowiązuje inna zasada - jeżeli żaden z pretendentów w pierwszej turze nie uzyska ponad 50\% głosów przy $40 \%$ frekwencji, to w drugiej turze rywalizują się dwóch kandydatów, którzy uzyskali najwięcej głosów w pierwszej.

$4 \mathrm{~W}$ tym ustawa o finansowaniu i kontroli finansowania kampanii politycznych, ustawa o partiach politycznych, ustawa o wywiadzie kryminalnym, ustawa o dobroczynności i pomocy, ustawa o godzeniu interesów publicznych i prywatnych, kodeks karny i kodeks przestępstw administracyjnych. 
o prawie wyborczym od 2019 r. Trybunał Konstytucyjny Republiki Litewskiej przyjmuje indywidualne skargi konstytucyjne (Lietuvos Respublikos Seimo rinkimai, 2021). Istniejące nowe ramy prawne zasadniczo zapewniają solidną podstawę dla demokratycznych wyborów.

\section{Nowe techniki głosowania w okresie pandemii}

W ustawodawstwie litewskim przewidziano szereg alternatywnych metod głosowania, m.in. prawo wybrania lokalu wyborczego znajdującego się w okręgu jednomandatowym innym niż ten w zadeklarowanym przez wyborcę miejscu zamieszkania, a także głosowanie przedterminowe, $\mathrm{z}$ domu lub $\mathrm{z}$ innych miejsc publicznych (najczęściej instytucji) wskazanych przez administrację wyborczą.

Także głosowanie korespondencyjne było dostępne dla wyborców wyjeżdżających za granicę, którzy mogli wyrazić swoją wolę w 51 lokalach wyborczych utworzonych w ambasadach i konsulatach Republiki Litewskiej. Po raz pierwszy w historii Litwy utworzono także jednomandatowy okręg wyborczy Litwinów Świata mieszkających poza granicami kraju.

Po przeprowadzonej naradzie z Ministerstwem Zdrowia, Centralna Komisja Wyborcza postanowiła zatwierdzić nadzwyczajną procedurę organizacji wyborów w okresie panującej pandemii. Procedura ta ustalała fundamentalne reguły postępowania, do których należały: zakrywanie ust i nosa, utrzymanie dystansu fizycznego, częsta dezynfekcja rąk i dotykanych powierzchni w lokach wyborczych, regulowanie strumieni wyborców w celu uniknięcie tłoku oraz zagwarantowanie przeprowadzenia bezpiecznego przebiegu procesu głosowania (Kuczyńska-Zonik, 2020).

Ze względu na panującą pandemię postanowiono również, iż krąg wyborców upoważnionych do głosowania $\mathrm{w}$ domu poszerzy się o dodatkowe grupy wyborców ${ }^{5}$. Wśród tych grup znalazły się osoby opiekujące się niepełnosprawnymi $\mathrm{w}$ domu oraz w pierwszej turze - osoby znajdujące się w izolacji na COVID-19 (głosujące w domu). W drugiej turze wyborcy ci mieli możliwość głosowania z samochodu w wyznaczonych lokalach wyborczych ${ }^{6}$.

5 Do tego czasu mogła to być grupa wyborców niepełnosprawnych, osoby okresowo niezdolne do pracy ze względy na stan zdrowia oraz osoby powyżej 70. roku życia.

6 W obu turach wyborów wyborcy, którzy wrócili z zagranicy lub mieli kontakt $\mathrm{z}$ osoba zakażoną, mogli ubiegać się o głosowanie w domu. W drugiej turze stworzono dodatkową okazję, otwierając 
Specyficznym rozwiązaniem, jakie wprowadziła Litwa, a którego nie zastosowano w innych państwach, było otwarcie mobilnych punktów wyborczych w Wilnie. W punktach tych wyborcy bez wysiadania z swojego samochodu mogli oddawać swój głos w przedterminowym głosowaniu ${ }^{7}$. Do skorzystania $\mathrm{z}$ takiej możliwości nie byli uprawnieni obywatele będący w izolacji z powodu pandemii COVID-19. Koncepcja otwarcia mobilnych punktów wyborczych stanowiła swoistą odpowiedź na duże zainteresowanie głosowaniem przedterminowym. Procedura umożliwiająca obywatelom oddanie głosu w mobilnym punkcie wyborczym zawierała zobowiązanie obywatela do jednoosobowego przebywania w aucie celem zachowania zasady tajności głosowania. Po ustaleniu tożsamości osoby członek komisji wyborczej wydawał karty do głosowania, które po wypełnieniu obywatel wkładał do koperty, zaklejał i zwracał (W Wilnie działa mobilny punkt wyborczy, 2020).

\section{Kampania wyborcza w czasie pandemii}

Oficjalnie okres kampanii wyborczej rozpoczął się wraz z ogłoszeniem wyborów przez prezydenta Republiki Litewskiej w kwietniu 2020 r. Ze względu na wprowadzone restrykcje, częściowo wskutek pojawienia się pandemii COVID$19 \mathrm{w}$ marcu 2020 r. ograniczono możliwość prowadzenia kampanii wyborczej. Kandydaci na posłów do Sejmu nie mogli w sposób niezakłócony prowadzić kampanii z uwagi na zakaz nieuzasadnionego opuszczania miejsca zamieszkania oraz zakazu organizacji wieców politycznych, zebrań, zgromadzeń itp. Z tego względu kandydaci nie mogli w pełni korzystać ze swojego biernego prawa wyborczego przejawiającego się także w możliwości prowadzenia agitacji i kampanii wyborczej.

Ze względu na powyższe ograniczenia oraz lockdown niemożliwe było prowadzenie kampanii wyborczej w tradycyjnej formie. W związku z tym większość działań kampanijnych przeniesiona została do internetu. Z uwagi na fakt, że nie każdy wyborca miał dostęp do internetu, gdzie prezentowali się kandydaci i partie polityczne, wyborcy nie mieli pełnego dostępu do informacji na temat

cztery lokale wyborcze dla takich przypadków w Wilnie, Kownie, Szawlach i Rosienie. Wyborcy, u których zdiagnozowano zakażenie COVID-19, mogli głosować tylko w domu.

7 Głosowanie przedterminowe w Republice Litewskiej możliwe było od poniedziałku do czwartku w tygodniu poprzedzającym dzień wyborów. W związku z panującą pandemią głosowanie przedterminowe wydłużono do czterech dni. 
kandydatów, ich programów politycznych itp. Jednocześnie należy zauważyć, że nie wszyscy kandydaci mieli równy dostęp do tradycyjnych mediów. Jak wskazują raporty powyborcze - prym w tym zakresie wiedli kandydaci partii rządzących, którzy promowani byli w mediach publicznych, m.in. poprzez nierówny podział czasu antenowego dedykowanego poszczególnym partiom lub kandydatom. Niektórzy kandydaci i eksperci wyrażali niezadowolenie $\mathrm{z}$ takiego formatu, który - ich zdaniem - nie ułatwiał wymiany poglądów informacji ani też nie pomagał wyborcom w podjęciu świadomej decyzji (Lietuvos Respublikos Seimo rinkimai, 2021).

Z powyższego można wywnioskować, iż wybory przeprowadzone w okresie pandemii koronawirusa mogą budzić wiele zastrzeżeń dotyczących realizacji zasad wolnych i równych wyborów - ograniczone możliwości prowadzenia kampanii wyborczej są dobrym przykładem w tym kontekście.

Jeśli chodzi o tematykę kampanijną - zauważyć należy, że debatę publiczną zdominowały kwestie gospodarcze i społeczne, środowisko naturalne, zdrowie oraz kwestie zarządzania kryzysowego związane z falą wzrostu zachorowań na COVID-19 (Wybory parlamentarne na Litwie, 2020). Warto odnotować, że w wyborach z 2020 r. zaobserwowano pozytywną zmianę, tj. kandydaci częściej niż we wcześniejszych elekcjach podejmowali dyskusje na temat udziału wyborców z niepełnosprawnościami i ich roli w życiu politycznym Litwy.

W trakcie kampanii większą uwagę niż w poprzednich wyborach poświęcono kandydatkom i kobietom - przewodniczącym partii politycznych oraz liderkom list partyjnych (2020 M. SPALIO 11 D. LIETUVOS RESPUBLIKOS SEIMO RINKIMAI, 2020) ${ }^{8}$, a także kwestiom równości płci i praw kobiet (LITHUANIAN PARLIAMENTARY ELECTIONS 2020:NOTABLE NARRATIVES, 2020). Natomiast partia polityczna, która w swoim programie włączyła kwestie małżeństw osób tej samej płci, otrzymała duży napływ negatywnych informacji w dyskursie publicznym (Lietuvos Respublikos Seimo rinkimai, 2021). Pojawiały

8 Jedna trzecia uczestników tych wyborów stanowiły kobiety, a 3 z 17 partii politycznych, które wzięły udział w wyborach, były kierowane przez kobiety. Na liście kandydatów jednej partii było więcej kobiet niż mężczyzn. Tylko jedna partia ustaliła parytety płci. Nowo wybrany Sejm z 2020 r. składa się z 38 posłanek (27\%). W obecnym rządzie jest siedem kobiet, w tym premier. Interesującym jest fakt, iż Akcja Wyborcza Polaków na Litwie zgłosiła do listy wyborczej do Sejmu 88 kobiet i 52 mężczyzn w okręgach wielomandatowych oraz 16 kobiet i 19 mężczyzn w okręgach jednomandatowych. Litewska Partia Socjaldemokratyczna zastosowała 40\% parytet płci dla listy kandydatów w okręgu wielomandatowym. Zob. 2020 M. SPALIO 11 D. LIETUVOS RESPUBLIKOS SEIMO RINKIMAI https://www. vrk.lt/documents/10180/714176/Easy+to+read_2020.pdf/328f6f93-492f-4fc3-8cc9-ee310calbf81. 
się przypadki zgłoszeń do prokuratury z powodu podżegania i mowy nienawiści, co miało związek z faktem, iż w litewskiej świadomości wciąż panuje pogląd wskazujący na brak tolerancji wobec mniejszości seksualnych i dyskryminację tych grup.

\section{Frekwencja oraz wyniki wyborów}

Poniżej zaprezentowano wyniki wyborów z 2020 r. do Sejmu Republiki Litewskiej. Ugrupowania polityczne uszeregowano na podstawie liczby uzyskanych głosów. W wyborach brało udział 17 partii i koalicji. Siedemnaście z nich wystawiło listy partyjne w wielomandatowym okręgu Litwy. Oprócz tego w wyborach w okręgach jednomandatowych brali udział kandydaci startujący pod własnym nazwiskiem, natomiast liczba kandydatów startujących jako niezależni wyniosła 23 kandydatów (Kandidatai vienmandatėse rinkimų apygardose, 2020).

W nawiązaniu do wyników poszczególnych ugrupowań politycznych, zdecydowanie wyróżniają się dwie partie, tj. Związek Ojczyzny - Chrześcijańscy Demokraci oraz Litewski Związek Rolników i Zielonych - mający wyraźną przewagę nad innymi partiami (patrz tabela 1). Podobnie jak w poprzednich wyborach zwycięska partia nie uzyskała bezwzględnej większości mandatów w Sejmie, co zmusiło ją do zawarcia koalicji rządowej. Zgodnie z danymi Centralnej Komisji Wyborczej Związek Ojczyzny - Chrześcijańscy Demokraci zapewnili sobie 50 mandatów. Rządząca Partia, czyli Litewski Związek Rolników i Zielonych, uzyskała 32 mandaty. Należy również zauważyć, iż prawica zdobyła większość mandatów zarówno w puli większościowej, jak i w proporcjonalnej.

Analizując liczbę mandatów uzyskanych przez partie polityczne w puli większościowej, jak i proporcjonalnej, obydwa te porównania mogą świadczyć, iż w ramach wykorzystywania głosów pierwszych wyborcy zachowywali się tradycyjnie zgodnie z prawem (empirycznym) mówiącym, że wybory większościowe zachęcają do głosowania na ugrupowania duże, starsze, o ugruntowanej pozycji w systemie partyjnym (Jarentowski, 2013). 
Tabela 1. Wyniki wyborów do Sejmu litewskiego w 2020 roku

\begin{tabular}{|c|c|c|c|c|c|c|c|c|c|c|}
\hline \multirow{3}{*}{$\begin{array}{l}\text { Partia politycz- } \\
\text { na, koalicja }\end{array}$} & \multicolumn{3}{|c|}{$\begin{array}{c}\text { Ogólnokrajowy okręg } \\
\text { wyborczy }\end{array}$} & \multicolumn{6}{|c|}{ Okręgi jednomandatowe } & \multirow{3}{*}{$\begin{array}{c}\text { Razem } \\
\text { mandaty }\end{array}$} \\
\hline & \multicolumn{9}{|c|}{ I tura II tura } & \\
\hline & Głosy & $\%$ & $\begin{array}{r}\text { Man- } \\
\text { daty }\end{array}$ & Głosy & $\%$ & $\begin{array}{l}\text { Man- } \\
\text { daty }\end{array}$ & Głosy & $\%$ & Mandaty & \\
\hline $\begin{array}{l}\text { Związek } \\
\text { Ojczyzny } \\
\text { - Chrześcijańscy } \\
\text { Demokraci }\end{array}$ & 292124 & 24,8 & 23 & & & 1 & & & 26 & 50 \\
\hline $\begin{array}{l}\text { Litewski Związek } \\
\text { Rolników } \\
\text { i Zielonych }\end{array}$ & 204791 & 17,43 & 16 & & & 0 & & & 16 & 32 \\
\hline Partia Pracy & 110773 & 9,43 & 9 & & & 0 & & & 1 & 10 \\
\hline $\begin{array}{l}\text { Litewska Partia } \\
\text { Socjaldemokra- } \\
\text { tyczna }\end{array}$ & 108649 & 9,25 & 8 & & & 0 & & & 5 & 13 \\
\hline $\begin{array}{l}\text { Partia } \\
\text { Wydolności }\end{array}$ & 107093 & 9,11 & 8 & & & 0 & & & 3 & 11 \\
\hline $\begin{array}{l}\text { Ruch Liberalny } \\
\text { Republiki } \\
\text { Litewskiej }\end{array}$ & 79755 & 6,79 & 6 & & & 0 & & & 7 & 13 \\
\hline $\begin{array}{l}\text { Akcja Wyborcza } \\
\text { Polaków na } \\
\text { Litwie - ZCHR }\end{array}$ & 56386 & 4,80 & 0 & & & 2 & & & 1 & 3 \\
\hline $\begin{array}{l}\text { Litewska Socjal- } \\
\text { demokratyczna } \\
\text { Partia Pracy }\end{array}$ & 37197 & 3,17 & 0 & & & 0 & & & 3 & 3 \\
\hline $\begin{array}{l}\text { Partia Centrum } \\
\text { - Nacjonaliści }\end{array}$ & 26769 & 2,28 & 0 & & & 0 & & & - & 0 \\
\hline $\begin{array}{l}\text { Związek } \\
\text { Narodowy }\end{array}$ & 25098 & 2,14 & 0 & & & 0 & & & - & 0 \\
\hline $\begin{array}{l}\text { Wolność } \\
\text { i Sprawiedliwość }\end{array}$ & 23355 & 1,99 & 0 & & & 0 & & & 1 & 1 \\
\hline $\begin{array}{l}\text { Litewska Partia } \\
\text { Zielonych }\end{array}$ & 19303 & 1,64 & 0 & & & 0 & & & 1 & 1 \\
\hline Droga odwagi & 13337 & 1,14 & 0 & & & 0 & & & - & 0 \\
\hline $\begin{array}{l}\text { Litwa - dla } \\
\text { wszystkich }\end{array}$ & 11352 & 0,97 & 0 & & & 0 & & & - & 0 \\
\hline
\end{tabular}




\begin{tabular}{|c|c|c|c|c|c|c|c|c|c|c|}
\hline \multirow{3}{*}{$\begin{array}{l}\text { Partia politycz- } \\
\text { na, koalicja }\end{array}$} & \multicolumn{3}{|c|}{$\begin{array}{c}\text { Ogólnokrajowy okręg } \\
\text { wyborczy }\end{array}$} & \multicolumn{6}{|c|}{ Okręgi jednomandatowe } & \multirow{3}{*}{$\begin{array}{c}\text { Razem } \\
\text { mandaty }\end{array}$} \\
\hline & \multicolumn{9}{|c|}{ I tura II tura } & \\
\hline & Głosy & $\%$ & $\begin{array}{l}\text { Man- } \\
\text { daty }\end{array}$ & Głosy & $\%$ & $\begin{array}{l}\text { Man- } \\
\text { daty }\end{array}$ & Głosy & $\%$ & Mandaty & \\
\hline $\begin{array}{l}\text { Unia } \\
\text { Chrześcijańska }\end{array}$ & 8825 & 0,75 & 0 & & & 0 & & & - & 0 \\
\hline $\begin{array}{l}\text { Unia Solidar- } \\
\text { ności i Między- } \\
\text { pokoleniowej } \\
\text { - Spójność dla } \\
\text { Litwy }\end{array}$ & 5808 & 0,49 & 0 & & & 0 & & & - & 0 \\
\hline $\begin{array}{l}\text { Litewska Partia } \\
\text { Ludowa }\end{array}$ & 2946 & 0,25 & 0 & & & 0 & & & - & 0 \\
\hline $\begin{array}{l}\text { Nieważne/puste } \\
\text { głosy }\end{array}$ & 41465 & - & - & & & - & & & - & - \\
\hline Niezależni & 0 & 0 & 0 & & & 0 & & & 4 & 4 \\
\hline Razem & 1175026 & 100 & 70 & & & 3 & & & 68 & 141 \\
\hline
\end{tabular}

Źródło: Balsavimo Rezultatai, 2020 .

Frekwencja w wyborach wyniosła 47,8 i była najniższa od 1989 r.

Zastanawiając się, nad przyczynami niskiej frekwencji wyborczej, należy dopatrywać się, ich w obawach społeczeństwa przed zarażeniem się, wirusem oraz we wprowadzonych w okresie kampanii wyborczej restrykcjach związanych z pandemią. Wybory parlamentarne, pomimo iż odbyły się w planowanym terminie, przeprowadzane były w szczycie drugiej fali pandemii. W dniu 10 października 2020 r., tj. w dzień przedwyborczy, na Litwie odnotowano rekordową, dobową liczbę nowych zakażeń - 205 przypadków, a w niedzielę 11 października było ich 160 . Należy również zwrócić uwagę, iż w tym okresie na terytorium całej Litwy panował wyższy wskaźnik śmiertelności niż wiosną i w miesiącach letnich. Frekwencja w tych wyborach również osłabiała negatywne nastawienie wyborców, że partie polityczne nie są w stanie samodzielnie rozwiązać problemów związanych z pandemią COVID-19. Pomimo że to ona dyktowała większość tematów kampanii, uderzając w koalicję rządzącą, Litewski Związek Rolników i Zielonych krytykowany był za słabe rezultaty w kwestii zarządzania 
kryzysowego. Pozostałe partie polityczne w swoich programach wyborczych nie zaproponowały konkretnych nowych działań w celu zapobiegania szerzenia się zakażeń wirusem COVID-19. Należy także zwrócić uwagę na fakt, iż ważną rolę odegrała sama kampania wyborcza, która przekształciła się w kampanię skoncentrowaną na zagadnieniach ekonomicznych, reformach zdrowotnych oraz kwestiach światopoglądowych (w tym legalizacji związków jednopłciowych) (Litwa: powrót do władzy konserwatystów, 2020).

\section{WNIOSKI}

Najważniejszym celem prowadzonych rozważań była analiza wpływu pandemii COVID-19 na wybory parlamentarne na Litwie w październiku 2020 r. (zarówno w kontekście przyjętych regulacji prawnych, jak i konsekwencji tych regulacji, samego przebiegu głosowania i poprzedzającej go kampanii wyborczej).

W badaniach podjęto się zweryfikowania hipotezy, zakładającej, że pandemia COVID-19 miała wpływ na proces organizacji i przebieg wyborów na Litwie oraz na poszczególne jej aspekty m.in.:

- na równość podmiotów rywalizujących - pomimo istotnych różnic w dostępie do czasu antenowego dla poszczególnych partii i kandydatów nie wyrażono większych obaw dotyczących nierównego traktowania partii politycznych przez władze, ich dostępu do mediów lub rozstrzyganie sporów wyborczych;

- regulacje dotyczące technik głosowania w warunkach reżimu sanitarnego - prawo litewskie przewidywało i zaoferowało szeroki zakres alternatywnych metod głosowania, w tym głosowanie przedterminowe, pocztowe, $w$ mobilnych punktach wyborczych oraz głosowanie poza granicami kraju. Wyborcy, którzy nie mogli udać się do swojego lokalu wyborczego w dniu wyborów, mogli głosować $\mathrm{z}$ wyprzedzeniem w lokalach udostępnionych przez jednostki samorządowe;

- tematy podnoszone przez partie w kampanii wyborczej - głównymi tematami kampanii były kwestie gospodarcze i społeczne, emerytury, energia i środowisko, zdrowie oraz pandemia COVID-19. Natomiast na przełomie września i października - z uwagi na fakt, iż Litwa w tym okresie mierzyła się z falą wzrostu zachorowań - debatę publiczną najbardziej zdominowała kwestia zarządzania kryzysowego.

Wyniki niniejszej analizy pozwalają odnieść się także do wspomnianych wcześniej badań Roberta Krimmera, Davida Dueñas-Cid, Julii Krivonosovej (2021), a także Magdaleny Musiał-Karg i Izabeli Kapsy (2021), w których 
stwierdza się, że najszybszym sposobem radzenia sobie z zarządzaniem bezpiecznych wyborów jest wprowadzenie dodatkowych środków higienicznych i przeprowadzenia wyborów w zaostrzonym reżimie sanitarnym. Takie właśnie środki zostały zastosowane na Litwie. Wspomniane rozwiązania - jak wskazują wymienieni wcześniej autorzy (Krimmer, Dueñas-Cid, Krivinosova, 2021; Musiał-Karg, Kapsa, 2021) są najbardziej skuteczne dla administracji wyborczej w perspektywie krótkoterminowej, jeśli chodzi o zarządzanie sytuacją pandemiczną w okresie wyborczym.

Kluczowym wyzwaniem, z jakim Litwa musiała się zmierzyć, było zagwarantowanie, by wybory parlamentarne w okresie pandemii spełniały standardy demokratyczne. Można stwierdzić, że pewne zastrzeżenia w tym zakresie budzi kilka faktów, wśród których wymienić można: wprowadzone w trakcie drugiej fali obostrzenia pandemiczne, tzw. twardy lockdown (m.in. poprzez wprowadzenie godzin policyjnych, zaostrzenie ograniczeń dotyczących kontaktów, w tym zakaz organizacji wydarzeń publicznych, zamknięcie większości sklepów, do minimum ograniczona była możliwość obywateli wychodzenia z domu, a poza teren powiatu można było wyjeżdżać tylko do pracy i w celach medycznych), ograniczona możliwość prowadzenia kampanii wyborczej w kraju. Kandydaci nie mieli możliwości prowadzenia kampanii w sposób niezakłócony z uwagi na zakaz nieuzasadnionego opuszczania miejsca zamieszkania, jak również zakaz organizacji wieców politycznych, zebrań, zgromadzeń itp. W związku z wystąpieniem tychże okoliczności, kandydaci nie mogli w pełni korzystać ze swojego biernego prawa wyborczego, które przejawia się m.in. w możliwości prowadzenia agitacji i kampanii wyborczej. W dobie pandemii, głównym miejscem prowadzenia debaty politycznej, prezentacji kandydatów oraz partii politycznych stały się dwa zasadnicze źródła: telewizja i internet.

Natomiast warto zauważyć, że w związku z pandemią wyborcom zaoferowano szeroki wachlarz alternatywnych metod głosowania: głosowanie przedterminowe, możliwość głosowania w okręgu jednomandatowym innym niż ten w którym głosowano na podstawie zadeklarowanego przez wyborcę miejsca zamieszkania oraz głosowanie w instytucjach, w domu, lub samochodach. Także wyborcy przebywający w samoizolacji w przypadku stwierdzonych syndromów COVID-19 mogli uczestniczyć w wyborach. Pomimo zaprezentowanych sondaży, w których wyborcy wyrażali swe zaufanie w stosunku do alternatywnych metod głosowania, ustawodawstwo nie przewidywało ujęcia określonych procedur co do których istnieje obawa, iż mogłyby mieć niekorzystny wpływ na ich wiarygodność (np. zaimplementowania i-voting). 
Pomimo, iż wybory były zorganizowane bardziej sprawniej niż poprzednie (co spowodowane było szerokim poziomem cyfryzacji procesu wyborczego oraz zagwarantowanym przeprowadzeniem bezpiecznego przebiegu procesu głosowania), frekwencja wyniosła 47,8 \%. Bezsprzecznie, kluczowym powodem niskiej frekwencji była pandemia koronawirusa, która miała fundamentalny wpływ na większość tematów kampanii, uderzając tym samym w obóz rządzący krajem - Litewski Związek Rolników i Zielonych. Pandemia pomogła również odnieść sukces opozycji prawicowej krytykującej decyzje rządu związane z rozprzestrzenianiem się pandemii COVID19.

Podsumowując, zaznaczyć warto, iż pomimo implementacji odpowiednich norm prawnych i zachowania gwarancji standardów demokratycznych oraz przeprowadzenia wyborów w sposób bezpieczny dla zdrowia głosujących i pracujących w komisjach wyborczych - w wyborach parlamentarnych roku 2020 odnotowano najniższy od wielu lat poziom zaangażowania wyborczego obywateli. Niska frekwencja była spowodowana nadzwyczajną sytuacją w kraju i na świecie, co przekładało się na poczucie zagrożenia bezpieczeństwa zdrowotnego obywateli, a to z kolei skutkowało mniejszym niż wcześniej udziałem w wyborach.

\section{BIBLIOGRAFIA:}

2020 M. SPALIO 11 D. LIETUVOS RESPUBLIKOS SEIMO RINKIMAI (2020). Pobrane z: https://www.vrk.lt/documents/10180/714176/Easy+to+read_2020.pdf/328f6f93492f-4fc3-8cc9-ee310calbf81.

Balsavimo Rezultatai (2020). Pobrane z: https://www.vrk.lt/2020-seimo/rezultatai.

Birch, S., Buril, F., Cheeseman, N., Clark, A., Darnolf, S., Dodsworth, S., Garber, L., Gutiérrez-Romero, R., Hollstein, T., James, T., Vasu Mohan, T., And Sawyer, K. (2020). How to hold elections safely and democratically during the COVID-19 pandemic, The British Academy. Pobrane z: https://www.thebritishacademy.ac.uk/documents/2632/How-to-hold-elections-safely-democratically-Shape-the-Future.pdf.

Eriksson, L. M., (2017). Natural Disasters and National Election On the 2004 Indian Ocean Boxing Day Tsunami, the 2005 Storm Gudrun and the 2006 Historic Regime Shift. Digital Comprehensive Summaries of Uppsala Dissertations from the Faculty of Social Sciences 136. ss. 71.

Eriksson, L.M. (2016). "Winds of Change. Voter Blame and Storm Gudrun in the 2006 Swedish Parliamentary Election”, Electoral Studies, 41, 129-142. DOI: 10.1016/j. electstud.

Gutman, A. (1998). Demokracja. W: E. Goodin, Ph. Pettit (red.). Przewodnik po wspótczesnej filozofii politycznej. Warszawa: Książka i Wiedza. 
James, T. S., Alihodzic, S. (2020). When Is It Democratic to Postpone an Election? Elections During Natural Disasters, COVID-19, and Emergency Situations, Election Law Journal, 19 (3), 344-362. DOI: 10.1089/elj.2020.0642.

James, T. S., Clarc, A.. (2021). Delivering electoral integrity under pressure: local government, electoral administration, and the 2016 Brexit referendum, Local Government Studies, 47(2), 186-207. DOI: 10.1080/03003930.2020.1719075.

Jarentowski, M. (2013). Mieszany system wyborczy w wersji kombinacyjnej, jako sposób wzmocnienia dużych partii politycznych na przykładzie Litwy. Przegląd Politologiczny, 4, 237-250. DOI: 10.14746/pp.2013.18.4.15.

Kandidatai vienmandatese rinkimu apygardose (2020). Pobrane $\mathrm{z}$ : https://www.vrk. lt/2020 sei/kandidatai?srcUrl=/rinkimai/1104/rnk1424/kandidatai/SeiKandidataiApygardose.html.

Krimmer R., Dueñas-Cid D., Krivonosova J. (2021). Debate: safeguarding democracy during pandemics. Social distancing, postal, or internet voting - the good, the bad or the ugly? Public Money \& Management, 41(1), 8-10. DOI: 10.1080/09540962.2020.1766222.

Kuczyńska-Zonik, A. (2020). Litwa po pierwszej turze wyborów parlamentarnych. IEŚ, 267. Pobrane z: https://ies.lublin.pl/wp-content/uploads/2020/10/ies-komentarze-267-170-2020.

Lietuvos Respublikos Seimo kanceliarija (2020). Pobrane z: https://www.lrs.lt/sip/ getFile3?p_fid=27608.

Lietuvos Respublikos Seimo rinkimai 2020 m. spalio 11 ir 25d. (2021). Warszawa.

Lietuvos Respublikos vyriausioji rinkimu komisija (2020). Pobrane z: http://www.vrk.lt/ lt/pirmas-puslapis/rinkimai/rinkimai-pagal-data.html.

Lietuvos Respublikos Vyriausioji rinkimu komisija. Rinkimai pagal rūš̨ (2012). Pobrane z: http://www.vrk.lt/lt/pirmas-puslapis/rinkimai/rinkimai-pagal-rusi.html.

LITHUANIAN PARLIAMENTARY ELECTIONS 2020:NOTABLE NARRATIVES (2020). Pobrane z: https://www.eesc.lt/wp-content/uploads/2020/12/v04_Election-monitoring-tekstas_be-virs_A4.pd.

Litwa: powrót do władzy konserwatystów (2020). Pobrane z: https://www.osw.waw.pl/pl/ publikacje/analizy/2020-10-26/litwa-powrot-do-wladzy-konserwatystow.

Martin-Rozumilowicz, B. (2020). Poland Yet Again Cast in the Role of Democracy's, Bellwether. Pobrane z: https://www.tol.org/client/article/28876-poland-yet-againcast-in-the-role-of-democracys-bellwether.html.

Massicotte, L., Blais, A. (1999). Mixed electoral systems: a conceptual and empirical survey. Electoral Studies, 3, 341-366. DOI:10.1016/S0261-3794(98)00063-8.

Musiał-Karg, M., Kapsa, I. (2020). All-postal voting (powszechne głosowanie korespondencyjne) w wyborach prezydenckich w Polsce w 2020 r. O tym, jak nie procedować w czasie pandemii? W: K. Hajder, M. Musiał-Karg, M. Górny (red.). Konsekwencje pandemii COVID-19. Państwo i społeczeństwo (ss. 135-145). Poznań: Wydawnictwo Naukowe Wydziału Nauk Politycznych i Dziennikarstwa. 
Musiał-Karg, M., Kapsa, I. (2020). Alternatywne metody głosowania w opiniach Polaków. Postawy i poglądy względem wybranych form partycypacji w wyborach. Poznań: Wydawnictwo Naukowe Wydziału Nauk Politycznych i Dziennikarstwa.

Musiał-Karg, M., Kapsa, I. (2021). Debate: Voting challenges in a pandemic - Poland. Public Money \& Management, 41(1), 6-8. DOI: 10.1080/09540962.2020.1809791.

Musiał-Karg, M. (2016). Alternative Voting Methods Through the Example of Postal Voting and E-Voting in Switzerland. Białostockie Studia Prawnicze, 20/A en, 13-23. DOI: 10.15290/bsp.2016.20A.en.01.

Oficialosios statistikos portalas. Pobrane z: https://osp.stat.gov.lt/statistiniu-rodikliu-analize?hash=103cad31-9227-4990-90b0-8991b58af8e7\#.

Onasz, M. (2020). Możliwość zachowania demokratycznego charakteru wyborów przeprowadzanych $w$ warunkach epidemii/pandemii. Zespół badań wyborczych. Pobrane z: https://pierzgal.github.io/zespolbadanwyborczych/blog/mo-liwo-zachowania-demokratycznego-charakteru-wybor\%C3\%B3w-przeprowadzanych-w-warunk ach-epidemii-pandemii.

Papla, M. (2010). System partyjny Litwy. W: B. Kosowska-Gąstoł (red.). Systemy partyjne państw Unii Europejskiej (ss.193-206). Kraków: Wydawnictwo Uniwersytetu Jagiellońskiego.

Raś, K. (2020). Wybory parlamentarne na Litwie. PISM, 76. Pobrane z: https://pism.pl/ publikacje/Wybory_parlamentarne_na_Litwie.

Repucci, S., Slipowitz, A. (2020). Democracy under Lockdown. The Impact of COVID19 on the Global Struggle for Freedom. Freedom House. Pobrane z: https://freedomhouse.org/sites/default/files/2020-10/COVID-19_Special_Report_Final_.pdf.

Seitz, S. T., M. Davis, M. (1984). The political matrix of natural disasters: Africa and Latin America, International Journal of Mass Emergencies and Disasters, 2, 231-250. Spinelli, A. (2020). Managing Elections under the COVID-19 Pandemic: The Republic of Korea's Crucial Test. International IDEA Technical, Paper no 2. Pobrane z: https://doi.org/10.31752/idea.2020.15. https://www.idea.int/publications/catalogue/ managing-elections-under-covid-19-pandemic-republic-korea-crucial-test.

Szcześciło, D. (2016). Mieszany system wyborczy w państwach Europy Środkowej $i$ Wschodniej, ss. 1-10. Pobrane z: https://www.batory.org.pl/upload/files/Programy\%20operacyjne/Masz\%20Glos/Policy\%20Paper\%20Dawida\%20Szescilo.pdf. Vaigauskas, Z. (2013). Wybory w Republice Litewskiej: oczekiwania i rzeczywistość. W: Prawo wyborcze i system partyjny na Litwie i w Polsce. Teoria i Praktyka. Wilno: Główna Komisji Wyborczej Republiki Litewskiej.

Vardys, V. (1993). Lietuvos Politine Kultura ir Laiko Reikalavimai (Lithuanian Political Culture and Requirements of the Time). Kowno: I Laisve' foundation.

W Wilnie działa mobilny punkt wyborczy (2020). Pobrane z: http://www.wilnoteka.lt/ artykul/w-wilnie-dziala-mobilny-punkt-wyborczy.

Wagner, R. (2020). Responding to COVID-19 with 100 per cent Postal Voting: Local Elections in Bavaria, Germany. Case study, September 2020, International Institute for Democracy and Electoral Assistance. Stockholm. Pobrane z: https://www.idea. 
int/sites/default/files/responding-to-covid-19-with-postal-voting-local-electionsin-bavaria.pdf.

Wybory parlamentarne na Litwie (2020). Pobrane z: https://www.pism.pl/publikacje/ Wybory_parlamentarne_na_Litwie.

Zieliński, J. (2003). Seimas. Parlament Litwy. Warszawa: Wydawnictwo Sejmowe. 